\title{
Effects of mannan-oligosaccharides-supplemented diets on production performance of four close-bred flocks of Japanese quail breeders
}

\author{
M. A. Iqbal I", A. Hussain ${ }^{2}$, N. Roohi ${ }^{3}$, M. I. Arshad ${ }^{4}$ \& O. Khan ${ }^{5}$ \\ ${ }^{1}$ Department of Zoology, Ghazi University Dera Ghazi Khan, Pakistan \\ ${ }^{2}$ Department of Wildlife \& Ecology, University of Veterinary \& Animal Sciences, Lahore, Pakistan \\ ${ }^{3}$ Department of Zoology, University of the Punjab, Lahore, Pakistan \\ ${ }^{4}$ Department of Forestry, Range \& Wildlife, Ghazi University, Dera Ghazi Khan, Pakistan \\ ${ }^{5}$ Departments of Zoology, Virtual University of Pakistan
}

(Received 2 February 2017; Accepted 8 March 2017; First published online 30 March 2017)

Copyright resides with the authors in terms of the Creative Commons Attribution 4.0 South African Licence.
See: http://creativecommons.org/licenses/by/4.0/za
Condition of use: The user may copy, distribute, transmit and adapt the work, but must recognise the authors and the South African
Journal of Animal Science.

\begin{abstract}
The present study was conducted to find out the dietary effects of mannan-oligosaccharides (MOS) supplemented diets on the production performance of four close-bred flocks (CBFs) of Japanese quail (Coturnix coturnix japonica) breeders. A total of 960 twelve-week-old birds of four CBFs were randomly divided into four groups $(n=240)$ with 12 replicates $(n=20)$. Birds were fed a corn-based basal diet or the same diet supplemented with $0.25 \%, 0.50 \%$, and $1.0 \%$ MOS for 15 weeks. The authors analysed the data by two-way ANOVA techniques using SAS (Statistical Analysis System). Birds fed MOS-supplemented diets had significantly higher body and egg weight, egg mass, and egg number than the control group. Similarly, the feed conversion ratio (FCR)/dozen eggs, FCR/kg egg mass, and mortality were significantly lower in MOS supplemented groups. However, no significant effect of MOS supplementation was recorded on feed intake and egg production of birds. None of the parameters differed significantly among CBFs. The results showed that feeding MOS as a replacement for antibiotic growth factor may positively influence the production performance and health of Japanese quail breeders.
\end{abstract}

Keywords: Body weight, egg weight, egg mass, feed conversion ratio, mortality

\# Corresponding author: anwariqbalk@yahoo.com

\section{Introduction}

Antibiotic growth promoters (AGPs) have normally been used to enhance the production performance of poultry and other farm animals. It has been thought that AGPs reduce toxin levels (Feighner \& Dashkevicz, 1987) and growth-depressing metabolites (Niewold, 2007) produced by the bacteria of gastrointestinal tract (GIT) and thus promote growth and feed efficiency. It is well known that AGP usage with beneficial effects has also created potential problems, such as the resistance of pathogens to certain recommended AGPs, which ultimately causes severe human health problems (Abaza et al., 2008; Attia et al., 2012). Regarding health issues, the prophylactic usage of the AGP remained under severe scientific and public scrutiny (Roe \& Pillai, 2003), until the European Union imposed bans on sub-therapeutic usage of AGPs in animal production in 2006 (Burch, 2006; Castanon, 2007). Now, it is necessary for the poultry industry to identify alternatives to AGPs to improve the production performance and health of animals (Janardhana et al., 2009).

Prebiotics, probiotics, and symbiotics are regarded as possible alternatives to AGPs. Prebiotics are non-digestible feed ingredients that affect the host beneficially by selectively stimulating the growth and activity of one or a limited number of intestinal bacteria (Gibson et al., 2004). These show beneficial effects on the gut by enhancing the digestion, absorption, and utilization of the nutrients (Gibson et al., 2005). Commonly used prebiotics are non-digestible carbohydrates such as trans-galacto oligosaccharides, fructo oligosaccharides, inulin, lactulose, MOS, some proteins, peptides and lipids (Dankowiakowska et al., 2013).

MOS, which are extracted from the outer cell wall of the yeast, are not hydrolysed by the host enzymes and fermented by intestinal microbiota (Lomax \& Calder, 2009). These provide competitive binding sites for pathogens such as Salmonella and Escherichia coli with mannose-specific type-1 fimbriae, decrease their attachment to the intestinal wall, and are ultimately excreted from the gut (Newman, 1994). MOS 
supplementation constantly increases the caecal populations of beneficial Lactobacillus and Bifidobacterium spp. (Rehman et al., 2009; Sadeghi et al., 2013).

The decrease in pathogens and increase in beneficial bacteria may be because of competition for receptor sites, and the production of volatile fatty acids, of some bacteriocins, and of $\lg A$ antibodies by the immune system of the host (Brzoska et al., 2007; Kim et al., 2009). Owing to these beneficial changes in microflora, the number of goblet cells and length of intestinal villi increase, which ultimately promotes the health and functions of the GIT of the host (Rehman et al., 2009; Bonos et al., 2010; Vahdatpour et al., 2011).

Supplementation with MOS has a positive influence on bodyweight, FCR, egg production, egg weight, fertility, and hatchability in poultry (Güçlü, 2011; Abd El-Samee et al., 2012). To date, few data are available regarding the growth-promoting effects of MOS in Japanese quail breeders. Therefore, the present study was designed to elucidate the effects of MOS supplementation on growth and production performance of four CBFs of Japanese quail breeders.

\section{Materials and Methods}

The study was conducted on 960 birds (12 weeks old) of four CBFs of Japanese quail breeders, namely Major, Kaleem, Sadat, and Zahid, which were maintained at Avian Research and Training Centre, University of Veterinary \& Animal Sciences, Lahore, Pakistan. The birds of each flock $(n=240)$ were further divided into four supplemental groups $(A, B, C$, and $D)$, being replicated in three groups $(n=20)$ in a completely randomized design (15 females +5 males). The birds were housed in French-made multi-deck cages. Each compartment of the cage provides the birds with separate feeding, drinking, breeding, and egg collection space. A programme of 17 hours of light was adopted.

The birds were fed a corn-based basal diet prepared in Hi-Tech Feed Industries (Pvt.), Lahore, Pakistan according to NRC (1994) standards (Table 1) or the same basal diet supplemented with various levels of MOS. Birds of groups A, B, and C were fed a basal diet supplemented with $0.25 \%, 0.50 \%$, and $1.0 \%$ MOS, respectively. However, birds of Group D were fed a basal diet only and were termed the control group. Water was provided through nipple drinkers and feed through trough feeders. Feed was added twice a day, in the morning and in the evening. No coccidiostats or antibiotics were added in the feed.

Table 1 Ingredients and chemical composition of experimental basal diet

\begin{tabular}{lclc}
\hline Ingredients & $\%$ & Nutrients & \\
\hline Maize & 30.0 & ME Kcal/kg & 2900 \\
Rice polish & 8.00 & CP & $20.00 \%$ \\
Canola meal & 10.0 & Ca & $3.00 \%$ \\
Soybean meal & 25.0 & Available P & $0.40 \%$ \\
Corn gluten $60 \%$ & 5.00 & Phytate P & $0.34 \%$ \\
Rice tips & 14.0 & Total P & $0.74 \%$ \\
Lime stone & 1.00 & Crude fibre & $4.38 \%$ \\
D-L Methionine & 0.10 & Linoleic acid & $1.00 \%$ \\
L-Lysine & 0.20 & Methionine & $0.50 \%$ \\
Threonine & 0.15 & Lysine & $1.30 \%$ \\
Soy oil & 1.85 & & \\
DCP & 1.50 & & \\
Vitamin premix & 0.20 & & \\
Molasses & 3.00 & & \\
\hline Total & 100 & &
\end{tabular}

ME: metabolizable energy; CP: crude protein

The weighed quantity of feed was offered twice a day in the morning and evening to each replicate. Residual feed and leftover feed was recorded daily to determine weekly feed consumption. Male and female birds were weighed on day 1 of the experiment by electronic digital analytical balance (Yueke, China), which 
is sensitive up to $0.001 \mathrm{~g}$, and subsequently at weekly intervals and at the end of experiment. Fresh eggs of each replicate were collected, counted, and weighed daily. Using this data, weekly egg numbers, egg weight, and egg mass were recorded accordingly.

Feed intake per $\mathrm{kg}$ of eggs ( $\mathrm{kg}$ feed/ $\mathrm{kg}$ eggs) and per dozen eggs ( $\mathrm{kg}$ feed/dozen eggs) was recorded weekly and utilized to calculate the FCR using these formulae (Fernando et al., 2008):

$$
\begin{gathered}
\text { FCR / dozen eggs }=\frac{\text { Feed consumed }(\mathrm{kg})}{\text { No. of eggs produced }} \times 12 \\
\text { FCR / kg egg mass }=\frac{\text { Feed consumed }(\mathrm{kg})}{\text { Egg mass }(\mathrm{kg})}
\end{gathered}
$$

Dead birds were removed from the experimental cages daily and recorded weekly to find the percentage mortality. Two-way ANOVA techniques were applied to analyse the data and interpreted by the general linear model (GLM) procedure (SAS, 2003). Duncan's multiple range (DMR) test (Duncan, 1955) was applied to compare the means (Steel et al., 1997).

\section{Results}

The results of the study revealed that the bodyweight of female birds (Table 2), egg weight, and egg mass were higher $(P<0.05)$ and egg production (Table 3$)$ was non-significantly higher in MOS-

\begin{tabular}{|c|c|c|c|}
\hline \multirow{2}{*}{ CBF } & \multirow{2}{*}{ MOS levels (\%) } & \multicolumn{2}{|c|}{ Parameters } \\
\hline & & Male & Female \\
\hline Major & & $260.64 \pm 2.60$ & $296.41 \pm 2.45$ \\
\hline Kaleem & & $257.33 \pm 1.95$ & $293.83 \pm 2.20$ \\
\hline Sadat & & $255.16 \pm 2.66$ & $294.10 \pm 2.20$ \\
\hline \multirow[t]{6}{*}{ Zahid } & & $257.27 \pm 3.54$ & $293.85 \pm 4.31$ \\
\hline & 0.25 & $257.60 \pm 2.08$ & $296.12^{a} \pm 2.23$ \\
\hline & 0.50 & $258.27 \pm 3.46$ & $297.91^{a} \pm 2.13$ \\
\hline & 1.00 & $258.84 \pm 3.28$ & $297.18^{a} \pm 1.60$ \\
\hline & 0.00 & $257.69 \pm 1.94$ & $286.56^{b} \pm 3.85$ \\
\hline & levels (\%) & & \\
\hline \multirow[t]{4}{*}{ Major } & 0.25 & $259.58 \pm 0.17$ & $292.81^{a, b, c} \pm 5.44$ \\
\hline & 0.50 & $253.33 \pm 8.80$ & $297.76^{\mathrm{a}, \mathrm{b}} \pm 6.59$ \\
\hline & 1.00 & $269.72 \pm 0.63$ & $291.47^{\mathrm{a}, \mathrm{b}, \mathrm{c}} \pm 2.76$ \\
\hline & 0.00 & $259.95 \pm 1.66$ & $302.10^{\mathrm{a}, \mathrm{b}} \pm 3.99$ \\
\hline \multirow[t]{4}{*}{ Kaleem } & 0.25 & $255.99 \pm 1.34$ & $299.53^{a, b} \pm 2.58$ \\
\hline & 0.50 & $264.11 \pm 3.98$ & $294.73^{\mathrm{a}, \mathrm{b}, \mathrm{c}} \pm 2.41$ \\
\hline & 1.00 & $256.22 \pm 4.25$ & $297.82^{\mathrm{a}, \mathrm{c}} \pm 2.35$ \\
\hline & 0.00 & $253.02 \pm 3.79$ & $283.24^{c} \pm 2.78$ \\
\hline \multirow[t]{4}{*}{ Sadat } & 0.25 & $251.88 \pm 2.42$ & $289.81^{\mathrm{b}, \mathrm{c}} \pm 4.35$ \\
\hline & 0.50 & $261.70 \pm 7.87$ & $295.71^{a, b, c} \pm 2.03$ \\
\hline & 1.00 & $255.26 \pm 7.60$ & $300.34^{a, b} \pm 3.76$ \\
\hline & 0.00 & $259.80 \pm 1.00$ & $290.38^{b, c} \pm 5.72$ \\
\hline \multirow[t]{4}{*}{ Zahid } & 0.25 & $262.97 \pm 7.34$ & $302.33^{\mathrm{a}, \mathrm{b}} \pm 1.89$ \\
\hline & 0.50 & $253.95 \pm 8.07$ & $303.45^{\mathrm{a}} \pm 4.90$ \\
\hline & 1.00 & $254.16 \pm 8.96$ & $299.09^{a, b} \pm 2.43$ \\
\hline & 0.00 & $257.98 \pm 7.01$ & $270.54^{d} \pm 2.88$ \\
\hline
\end{tabular}

Table 2 Average bodyweight (g) of quail parent flocks fed various levels of Mannan-oligosaccharides

Means within column with different letters are significantly different at $P<0.05$. Order of significance is as $a>b>c>d$ CBF: Close-bred flocks; MOS: Mannan-oligosaccharides 
supplemented groups than in the control group. However, the total number of eggs per week of Group B was significantly higher than those of the other treatment groups.

Table 3 Egg production (\%), egg number, egg weight and egg mass/bird of Japanese quail parent flocks fed various levels of Mannan-oligosaccharides

\begin{tabular}{|c|c|c|c|c|c|}
\hline \multirow{2}{*}{ CBF } & \multirow{2}{*}{$\begin{array}{c}\text { MOS levels } \\
(\%)\end{array}$} & \multicolumn{4}{|c|}{ Parameters } \\
\hline & & Egg production (\%) & Egg No. & Egg weight (g) & Egg mass $(g)$ \\
\hline Major & & $79.59 \pm 1.52$ & $5.57 \pm 0.09$ & $13.05 \pm 0.05$ & $72.79 \pm 1.32$ \\
\hline Kaleem & & $77.23 \pm 1.92$ & $5.42 \pm 0.13$ & $13.11 \pm 0.09$ & $71.27 \pm 2.00$ \\
\hline Sadat & & $80.70 \pm 1.64$ & $5.61 \pm 0.11$ & $13.01 \pm 0.08$ & $73.85 \pm 1.64$ \\
\hline \multirow[t]{5}{*}{ Zahid } & & $75.88 \pm 2.08$ & $5.31 \pm 0.14$ & $13.05 \pm 0.11$ & $69.61 \pm 2.23$ \\
\hline & 0.25 & $78.45 \pm 1.67$ & $5.49^{\mathrm{a}, \mathrm{b}} \pm 0.11$ & $13.08^{\mathrm{a}} \pm 0.07$ & $72.03^{\mathrm{a}} \pm 1.42$ \\
\hline & 0.50 & $80.31 \pm 1.54$ & $5.64^{\mathrm{a}} \pm 0.12$ & $13.19^{\mathrm{a}} \pm 0.05$ & $74.38^{\mathrm{a}} \pm 1.43$ \\
\hline & 1.00 & $80.05 \pm 1.81$ & $5.61^{a} \pm 0.10$ & $13.18^{\mathrm{a}} \pm 0.05$ & $74.16^{\mathrm{a}} \pm 1.86$ \\
\hline & 0.00 & $74.59 \pm 2.01$ & $5.17^{\mathrm{b}} \pm 0.13$ & $12.77^{\mathrm{b}} \pm 0.08$ & $66.93^{\mathrm{b}} \pm 1.88$ \\
\hline \multicolumn{6}{|c|}{ CBF $\times$ MOS levels $(\%)$} \\
\hline \multirow[t]{4}{*}{ Major } & 0.25 & $80.19 \pm 0.94$ & $5.64 \pm 0.08$ & $12.91^{\mathrm{c}, \mathrm{d}, \mathrm{e}} \pm 0.04$ & $72.71 \pm 1.10$ \\
\hline & 0.50 & $84.93 \pm 2.24$ & $5.88 \pm 0.14$ & $13.20^{\mathrm{a}, \mathrm{b}, \mathrm{c}} \pm 0.10$ & $78.00 \pm 1.57$ \\
\hline & 1.00 & $77.07 \pm 3.95$ & $5.46 \pm 0.24$ & $13.02^{\mathrm{a}, \mathrm{b}, \mathrm{c}, \mathrm{d}, \mathrm{e}} \pm 0.05$ & $70.38 \pm 3.26$ \\
\hline & 0.00 & $76.19 \pm 2.41$ & $5.31 \pm 0.13$ & $13.07^{\mathrm{a}, \mathrm{b}, \mathrm{c}} \pm 0.11$ & $70.05 \pm 1.89$ \\
\hline \multirow[t]{4}{*}{ Kaleem } & 0.25 & $76.48 \pm 4.47$ & $5.33 \pm 0.29$ & $13.30^{\mathrm{a}, \mathrm{b}} \pm 0.10$ & $70.99 \pm 4.01$ \\
\hline & 0.50 & $80.86 \pm 3.00$ & $5.67 \pm 0.20$ & $13.28^{a, b, c} \pm 0.12$ & $76.06 \pm 3.08$ \\
\hline & 1.00 & $79.74 \pm 2.87$ & $5.60 \pm 0.20$ & $13.20^{a, b, c} \pm 0.01$ & $73.85 \pm 2.79$ \\
\hline & 0.00 & $71.85 \pm 4.45$ & $5.06 \pm 0.31$ & $12.67^{\mathrm{e}, \mathrm{f}} \pm 0.12$ & $64.18 \pm 3.79$ \\
\hline \multirow[t]{4}{*}{ Sadat } & 0.25 & $82.48 \pm 1.07$ & $5.73 \pm 0.11$ & $12.92^{\mathrm{b}, \mathrm{c}, \mathrm{d}, \mathrm{e}} \pm 0.19$ & $75.12 \pm 0.97$ \\
\hline & 0.50 & $78.03 \pm 3.88$ & $5.44 \pm 0.24$ & $13.18^{\mathrm{a}, \mathrm{b}, \mathrm{c}, \mathrm{d}} \pm 0.03$ & $72.20 \pm 3.62$ \\
\hline & 1.00 & $81.76 \pm 5.87$ & $5.75 \pm 0.38$ & $13.15^{\mathrm{a}, \mathrm{b}, \mathrm{c}, \mathrm{d}} \pm 0.11$ & $75.78 \pm 6.17$ \\
\hline & 0.00 & $80.53 \pm 1.76$ & $5.52 \pm 0.10$ & $12.81^{\mathrm{e}, \mathrm{f}} \pm 0.20 \mathrm{~d}$ & $72.28 \pm 1.38$ \\
\hline \multirow[t]{4}{*}{ Zahid } & 0.25 & $74.64 \pm 4.56$ & $5.26 \pm 0.31$ & $13.21^{a, b, c} \pm 0.04$ & $69.30 \pm 4.09$ \\
\hline & 0.50 & $77.41 \pm 2.35$ & $5.44 \pm 0.16$ & $13.09^{\mathrm{a}, \mathrm{b}, \mathrm{c}, \mathrm{d}} \pm 0.18$ & $71.27 \pm 2.19$ \\
\hline & 1.00 & $81.65 \pm 2.51$ & $5.74 \pm 0.17$ & $13.34^{\mathrm{a}} \pm 0.16$ & $76.64 \pm 2.77$ \\
\hline & 0.00 & $69.82 \pm 5.09$ & $4.81 \pm 0.28$ & $12.54^{\dagger} \pm 0.03$ & $61.21 \pm 4.32$ \\
\hline
\end{tabular}

Means within column with different alphabets are different significantly at $P<0.05$. Order of significance is as: $\mathrm{a}>\mathrm{b}>\mathrm{c}>$ d

CBF: Close-bred flocks; MOS: Mannan-oligosaccharides

On the other hand, FCR/dozen eggs, FCR/kg egg mass, and mortality (Table 4) of MOSsupplemented groups were significantly lower than in the control group. However, neither MOS supplementation nor CBF significantly affected the overall feed intake of the birds during the 15-week experimental period. None of the parameters differed $(P<0.05)$ among CBFs.

In the interaction of CBF and MOS levels, significantly $(P<0.05)$ higher bodyweight was recorded in $0.50 \%$ MOS and egg weight in the $1.00 \%$ MOS-supplemented group of Zahid flock than in the control group of the same flock. FCR/dozen eggs was significantly lower $(P<0.05)$ in the $0.50 \%$ MOS-fed group of the Major flock and FCR/kg egg mass of the Zahid flock than in the control group of same flock. Similarly, mortality was significantly lower $(P<0.05)$ in the $1.0 \%$ MOS-supplemented group of the Kaleem flock than in the control group of the same flock. 
Table 4 Average feed intake, feed conversion ratio and mortality of Japanese quail parent flocks fed various levels of Mannan-oligosaccharides

\begin{tabular}{|c|c|c|c|c|c|}
\hline \multirow{2}{*}{ CBF } & \multirow{2}{*}{$\begin{array}{c}\text { MOS levels } \\
(\%)\end{array}$} & \multicolumn{4}{|c|}{ Parameters } \\
\hline & & Feed intake (kg) & FCR/egg mass (kg) & FCR/dozen egg (No) & Mortality (\%) \\
\hline Major & & $2.59 \pm 0.03$ & $3.16 \pm 0.06$ & $0.49 \pm 0.01$ & $1.18 \pm 0.07$ \\
\hline Kaleem & & $2.64 \pm 0.02$ & $3.27 \pm 0.10$ & $0.51 \pm 0.02$ & $1.13 \pm 0.19$ \\
\hline Sadat & & $2.71 \pm 0.03$ & $3.14 \pm 0.07$ & $0.49 \pm 0.01$ & $1.05 \pm 0.11$ \\
\hline Zahid & & $2.64 \pm 0.04$ & $3.37 \pm 0.12$ & $0.52 \pm 0.02$ & $1.46 \pm 0.12$ \\
\hline & 0.25 & $2.64 \pm 0.02$ & $3.21^{b} \pm 0.07$ & $0.50^{\mathrm{b}} \pm 0.01$ & $1.05^{\mathrm{b}} \pm 0.12$ \\
\hline & 0.50 & $2.70 \pm 0.04$ & $3.11^{b} \pm 0.06$ & $0.48^{\mathrm{b}} \pm 0.01$ & $1.23^{a, b} \pm 0.15$ \\
\hline & 1.00 & $2.64 \pm 0.03$ & $3.11^{b} \pm 0.08$ & $0.49^{b} \pm 0.01$ & $1.03^{b} \pm 0.12$ \\
\hline & 0.00 & $2.59 \pm 0.03$ & $3.52^{\mathrm{a}} \pm 0.11$ & $0.53^{\mathrm{a}} \pm 0.02$ & $1.51^{a} \pm 0.11$ \\
\hline \multicolumn{6}{|c|}{ CBF $\times$ MOS levels (\%) } \\
\hline \multirow[t]{4}{*}{ Major } & 0.25 & $2.63^{a, b} \pm 0.03$ & $3.15^{\mathrm{b}, \mathrm{c}} \pm 0.0$ & $0.48^{\mathrm{b}, \mathrm{c}} \pm 0.01$ & $1.12^{\mathrm{b}, \mathrm{c}, \mathrm{d}, \mathrm{e}} \pm 0.24$ \\
\hline & 0.50 & $2.64^{\mathrm{a}, \mathrm{b}} \pm 0.07$ & $2.93^{\mathrm{c}} \pm 0.05$ & $0.45^{c} \pm 0.01$ & $1.08^{\mathrm{b}, \mathrm{c}, \mathrm{d}, \mathrm{e}} \pm 0.0$ \\
\hline & 1.00 & $2.54^{\mathrm{b}} \pm 0.00$ & $3.25^{b, c} \pm 0.15$ & $0.50^{\mathrm{a}, \mathrm{b}, \mathrm{c}} \pm 0.03$ & $1.27^{\mathrm{a}, \mathrm{b}, \mathrm{c}, \mathrm{d}} \pm 0.13$ \\
\hline & 0.00 & $2.57^{b} \pm 0.08$ & $3.34^{b, c} \pm 0.06$ & $0.51^{a, b, c} \pm 0.02$ & $1.27^{\mathrm{a}, \mathrm{b}, \mathrm{c}, \mathrm{d}} \pm 0.12$ \\
\hline \multirow[t]{4}{*}{ Kaleem } & 0.25 & $2.67^{\mathrm{a}, \mathrm{b}} \pm 0.03$ & $3.25^{b, c} \pm 0.19$ & $0.52^{\mathrm{a}, \mathrm{b}, \mathrm{c}} \pm 0.03$ & $0.57^{\mathrm{e}, \mathrm{f}} \pm 0.12$ \\
\hline & 0.50 & $2.56^{\mathrm{b}} \pm 0.04$ & $3.05^{\mathrm{c}} \pm 0.13$ & $0.47^{b, c} \pm 0.03$ & $1.69^{a, b} \pm 0.12$ \\
\hline & 1.00 & $2.71^{a, b} \pm 0.02$ & $3.13^{b, c} \pm 0.12$ & $0.50^{\mathrm{a}, \mathrm{b}, \mathrm{c}} \pm 0.02$ & $0.46^{f} \pm 0.12$ \\
\hline & 0.00 & $2.61^{b} \pm 0.00$ & $3.66^{a, b} \pm 0.24$ & $0.55^{\mathrm{a}, \mathrm{b}} \pm 0.04$ & $1.81^{\mathrm{a}} \pm 0.14$ \\
\hline \multirow[t]{4}{*}{ Sadat } & 0.25 & $2.65^{a, b} \pm 0.06$ & $3.07^{c} \pm 0.03$ & $0.47^{b, c} \pm 0.01$ & $1.24^{\mathrm{a}, \mathrm{b}, \mathrm{c}, \mathrm{d}} \pm 0.26$ \\
\hline & 0.50 & $2.79^{\mathrm{a}} \pm 0.02$ & $3.21^{b, c} \pm 0.17$ & $0.51^{a, b, c} \pm 0.03$ & $0.70^{\mathrm{d}, \mathrm{e}, \mathrm{f}} \pm 0.20$ \\
\hline & 1.00 & $2.71^{a, b} \pm 0.03$ & $3.07^{\mathrm{C}} \pm 0.28$ & $0.48^{\mathrm{b}, \mathrm{c}} \pm 0.04$ & $1.00^{\mathrm{c}, \mathrm{d}, \mathrm{e}, \mathrm{f}} \pm 0.14$ \\
\hline & 0.00 & $2.66^{\mathrm{a}, \mathrm{b}} \pm 0.10$ & $3.22^{b, c} \pm 0.07$ & $0.49^{b, c} \pm 0.01$ & $1.26^{\mathrm{a}, \mathrm{b}, \mathrm{c}, \mathrm{d}} \pm 0.14$ \\
\hline \multirow[t]{4}{*}{ Zahid } & 0.25 & $2.62^{\mathrm{a}, \mathrm{b}} \pm 0.03$ & $3.37^{b, c} \pm 0.20$ & $0.53^{\mathrm{a}, \mathrm{b}, \mathrm{c}} \pm 0.03$ & $1.27^{\mathrm{a}, \mathrm{b}, \mathrm{c}, \mathrm{d}} \pm 0.15$ \\
\hline & 0.50 & $2.80^{\mathrm{a}} \pm 0.07$ & $3.24^{b, c} \pm 0.10$ & $0.51^{a, b, c} \pm 0.01$ & $1.44^{\mathrm{a}, \mathrm{b}, \mathrm{c}} \pm 0.38$ \\
\hline & 1.00 & $2.61^{b} \pm 0.06$ & $2.99^{c} \pm 0.11$ & $0.47^{b, c} \pm 0.02$ & $1.41^{\mathrm{a}, \mathrm{b}, \mathrm{c}} \pm 0.15$ \\
\hline & 0.00 & $2.54^{\mathrm{b}} \pm 0.07$ & $3.87^{\mathrm{a}} \pm 0.27$ & $0.58^{\mathrm{a}} \pm 0.03$ & $1.71^{\mathrm{a}, \mathrm{b}} \pm 0.31$ \\
\hline
\end{tabular}

Means within column with different alphabets are significantly different at $P<0.05$. Order of significance is as: $\mathrm{a}>\mathrm{b}>\mathrm{c}>$ d

CBF: Close-bred flocks; MOS: Mannan-oligosaccharides

\section{Discussion}

In the present study, significantly higher bodyweights of MOS-supplemented groups were supported by various earlier studies on the growth of quails (Bonos et al., 2010). Fritts \& Waldroup (2003) observed higher bodyweight in turkeys consuming a MOS-supplemented diet. Benites et al. (2008) and Bozkurt et al. (2009) found that the broilers of MOS-supplemented groups were heavier $(P<0.05)$ than the control group. Contrarily, Ghosh et al. (2007) and Sarica et al. (2009) did not notice significant change in bodyweight of quails among MOS-supplemented and control groups. In another study, Bonos et al. (2011) observed similar findings, and reported that MOS did not show significant effects on the live weight of laying Japanese quails.

The significantly heavier egg in MOS-supplemented groups is supported by earlier researchers. Hanan et al. (2010) recorded that oligosaccharides supplementation in the feed of laying birds increased $(P$ $<0.05)$ egg weight. Similarly, Gracia et al. (2004) noted a significant effect of MOS-supplemented diet on egg weight of laying hens. Abd El-Samee et al. (2012) observed that egg weight of quails was significantly higher in MOS-supplemented group than in the control. However, Bonos et al. (2011) and Güçlü (2011) could not find significant effects of MOS on egg weight of birds. 
The increase in bodyweight in the present study might be due to the healthy effects of MOS, which include the reduction of selected pathogens such as E. coli and Salmonella and their stress on intestinal mucosa. The increase of beneficial microbes and increase in villus height, strengthening the mucosa of gut and thus absorption and utilization of the dietary nutrients, resulted in heavier eggs and increased bodyweight (lqbal et al., 2015). The tendency of higher egg production was observed in the MOSsupplemented groups, but not in the control group; however, it was statistically not significant. Similar results were found by Tarasewicz et al. (2004), Güçlü (2011), and Bozkurt et al. (2012), who reported that oligosaccharides-supplemented diet increased the capacity of egg production. Increased egg production by MOS supplementation might be due to an increase in the intestinal length of birds, reduction of pathogens, and increased beneficial bacteria, which ultimately enhanced the absorptive ability of the intestine (Chen et al., 2005).

The significantly lower FCR per dozen eggs from MOS supplementation in the present study agrees with the findings of various researchers, who reported that MOS significantly lowered the FCR of quails and other poultry birds (Ghosh et al.,2007; Midilli et al., 2008). Hooge (2004) reported that Bio-MOS lowered FCR by $1.99 \%$ in comparison with the control group. In contrast, Fernando et al. (2008) observed that Bio-MOS did not show significant effects on FCR per dozen eggs. Similarly, Yalqnkaya et al. (2008) reported that MOS showed no effect on the FCR of broilers.

In the present study, significantly lower FCR per kg egg mass of MOS-supplemented groups agrees with the findings of Rosen (2007a), who reported that Bio-MOS reduced FCR by $2.43 \%$, whereas Bozkurt et al. (2012) reported that MOS did not show an impact on FCR. In contrast with these findings, Fernando et al. (2008) observed that Bio-MOS did not show any significant effects on FCR/kg egg mass. Lowering in FCR value is an indication of more and heavier egg production rates of the breeders by MOS supplementation, which might be due to more fermentation, digestion, and absorption of nutrients by altering the gut microbiota (Rehman et al., 2009). The significantly lower mortality of MOS-supplemented groups was similar to the findings of Cabuk et al. (2006), who reported that MOS-supplementation lowered the mortality rate. Rosen (2007b) reported that Bio-MOS reduced mortality by $0.46 \%$. However, Bonos et al. (2011) and Bozkurt et al. (2012) observed that MOS supplementation did not show any significant effect on the mortality of breeders. The decrease in the mortality of birds in the current study might be owing to the reduction of pathogenic load of the gut and improvement in health conditions of laying quails.

In the present study, neither MOS levels nor CBFs showed significant effects on overall feed intake in the control or MOS-supplemented groups. These results were in accordance with the findings of Ghosh et al. (2007), who observed non-significant differences in feed intake. Similar results have been reported in broilers by Midilli et al. (2008) and in quails by Ghosh et al. (2007). Güçlü (2011) reported that neither prebiotics nor probiotics showed significant effects on feed intake. Similarly, Bonos et al. (2011) reported that MOS did not show a significant effect on the feed intake in laying Japanese quails. In contrast, Bonos et al. (2010) reported that in growing quails, feed consumption increased significantly, whereas in two comparative studies Rosen (2007a; 2007b) reported that feed consumption of birds fed a MOS-supplemented diet was lower than those in the control group.

Based on these results, it is generally considered that MOS is a nutritional supplement that has potential to eliminate pathogens and support beneficial micro flora, promote the health of the GIT, and enhance the digestion and absorption of nutrients, thus improving overall health conditions, enhancing the growth rate and wellbeing of animals (Halas \& Nochta, 2012).

\section{Conclusion}

The addition of MOS to the diets of quail breeders enhanced the production performance and improved the health conditions of the birds. Out of four flocks of breeders, birds of the Zahid flock and, among treatment groups, birds feeding the $0.50 \%$ MOS-supplemented diet had the best production performance. In conclusion, $0.50 \%$ MOS-supplementation might be recommended in the diets of quail breeders, and quails of Zahid flock should be adopted for best production performance.

\section{Acknowledgements}

We cordially acknowledge Avian Research and Training Centre, Department of Poultry Production, UVAS, Lahore, Pakistan for the provision of birds and excellent research facilities.

\section{Authors' Contributions}

MAI designed the research project for his PhD studies and drafted the manuscript. NR supervised the research work. OK helped in laboratory work. AH critically analysed and interpreted results. MIA helped in preparing and drafting the manuscript. 


\section{Conflict of Interest Declaration}

None of the authors of this work has a financial or other relationship with people or organizations that could influence inappropriately or bias the contents of this paper.

\section{References}

Abaza, I.M., Shehata, M.A., Shoieb, M.S. \& Hassan, I.I., 2008. Evaluation of some natural feed additive in growing chicks' diets. Int. J. Poult. Sci. 7, 872-879.

Abd El-Samee, D.L., El-Wardany, I., Ali, N.G.\& Abo-El-Azab, O.M., 2012. Egg quality, fertility and hatchability of laying quails fed diets supplemented with organic zinc, chromium yeast or mannan-oligosaccharides. Int. J. Poult. Sci. 3, 221-224.

Attia, Y., Ellakany, H., El-Hamid, A.A., Bovera, F. \& Ghazaly, S., 2012. Control of Salmonella enteritidis infection in male layer chickens by acetic acid and/or prebiotics, probiotics and antibiotics. Arch Geflügelk 76, 239-245.

Benites, V., Gilharry, R., Gernat, A.G. \& Murillo, J.G., 2008. Effect of dietary Mannan-oligosaccharide from Bio-Mos or SAF-Mannan on live performance of broiler chickens. J. Appl. Poult. Res. 17, 471-475.

Bonos, E., Christaki, E. \& Florou-Paneri, P., 2010. Performance and carcass characteristics of Japanese quail as affected by sex or Mannan-oligosaccharides and calcium propionate. S. Afr. J. Anim. Sci. 40, 173-184.

Bonos, E., Christaki, E. \& Florou-Paneri, P., 2011. Effects of dietary Mannan-oligosaccharides and calcium formate on performance and egg quality of Japanese quail (Coturnix japonica). J. Food Sci. Eng. 1, 289-296.

Bozkurt, M., Küçükyılmaz, K., Çatlı, A.U. \& Çınar, M., 2009. Effect of dietary mannan oligosaccharide with or without oregano essential oil and hop extract supplementation on the performance and slaughter characteristics of male broilers. S. Afr. J. Anim. Sci. 39, 223-232.

Bozkurt, M., Tokuşog lu, Ö, Küçükyılmaz, K., Akşit, H., Çabuk, M., Çatli, A.U., Seyrek, K. \& Çınar, M., 2012. Effects of dietary mannan-oligosaccharide and herbal essential oil blend supplementation on performance and oxidative stability of eggs and liver in laying hens. Ital. J. Anim. Sci. 11, 223-229.

Brzoska, F., Buluchevskij, S., Stecka, K. \& Śliwiński, B., 2007. The effects of lactic acid bacteria and mannan oligosaccharide, with or without fumaric acid, on chicken performance, slaughter yield and digestive tract microflora. J. Anim. Feed Sci. 16, 241-251.

Burch, D. 2006. Anticipated effects of the withdrawal of antibiotic growth promoters (AGPs) from pigs in the European Union. Available at: http://wwwoctagon- servicescoUK/articles/withdrawalAGPhtm. Accessed August 2006.

Cabuk, M., Bozkurt, M., Alcicek, A., Catli, A.U. \& Baser, K.H.C., 2006. Effect of a dietary essential oil mixture on performance of laying hens in the summer season. S. Afr. J Anim. Sci. 26, 215-221.

Castanon, J.I.R., 2007. History of the use of antibiotic growth promoters in European poultry feeds. Poult. Sci. 86, 24662471.

Chen, Y.C., Nakthong, C. \& Chen, T.C., 2005. Improvement of laying hen performance by dietary prebiotic chicory oligofructose and inulin. Int. J. Poult. Sci. 4, 103-108.

Dankowiakowska, A., Kozłowska, I. \& Bednarczyk, M., 2013. Probiotics, Prebiotics and symbiotics in poultry mode of action, limitation, and achievements. J. Centr. Europ. Agri. 14, 467-478.

Duncan, D.B., 1955. Multiple-range and multiple-F tests. Biom. 11, 1-42.

Feighner, S.D. \& Dashkevicz, M.P., 1987. Subtherapeutic levels of antibiotics in poultry feeds and their effects on weight gain, feed efficiency, and bacterial cholyltaurine hydrolase activity. Appl. Environ. Microbiol. 53, 331-336.

Fernando, G.P.C., Nobre, I.S., Silva, L.P.G., Goulart, C.C., Figueiredo, D.F. \& Rodrigue, V.P., 2008. The use of prebiotic and organic minerals in rations for Japanese laying quails. Int. J. Poult. Sci. 7, 339-343.

Fritts, C.A. \& Waldroup, P.W., 2003. Evaluation of Bio-Mos $\AA$ mannan-oligosaccharide as a replacement for growth promoting antibiotics in diets for turkeys. Int. J. Poult. Sci. 2, 19-22.

Ghosh, H., Halder, G., Samanta, G., Paul, S.K. \& Pyne, S.K., 2007. Effects of dietary supplementation of organic acid and mannan-oligosaccharides on the performance and gut health of Japanese quail. Asi. J. Poult. Sci. 1, 1-7.

Gibson, G.R., McCarty, A.L. \& Rastall, R.A., 2005. Prebiotics and resistance to gastrointestinal infections. Br. J. Nutr. 93, Suppl 1 S 31-4.

Gibson, G.R., Probert, H.M., Van Loo J., Rastall, R.A. \& Roberfroid, M.B., 2004. Dietary modulation of the human colonic microbiota: Updating the concept of prebiotics. Nutr. Res. Rev. 17, 259-275.

Gracia, M.I., Cachaldora, P., Tucker, L., Baucells, F. \& Medel, P. 2004. Effect of mannan-oligosaccharides supplementation to laying hen diets, ADS ASAS PSA Annual Meeting, 25-29 July, 673, (abstract)

Güçlü, B.K., 2011. Effects of probiotic and prebiotic (mannan oligosaccharide) supplementation on performance, egg quality and hatchability in quail breeders. Ankara Üniv. Vet. Fak. Derg. 58, 27-32.

Halas, V. \& Nochta, I., 2012. Mannan oligosaccharides in nursery pig nutrition and their potential mode of action. Animals 2, 261-274.

Hanan, A.H., 2010. Variations in egg performance and plasma constituents at different ages of female Japanese quail. Egypt. Poult. Sci. 30, 565-581.

Hooge, D.M., 2004. Meta-analysis of broiler chicken pen trials evaluating dietary mannan oligosaccharide 1993-2003. Int. J. Poult. Sci. 3,163-174.

lqbal, M.A., Nabila, R., Akram, M. \& Omaima, K., 2015. Egg quality and egg geometry influenced by mannanoligosaccharides (MOS), a prebiotic supplementation in four close-bred flocks of Japanese quail breeders (Coturnix coturnix japonica). Pak. J. Zool. 47, 641-648.

Janardhana, V., Broadway, M.M., Bruce, M.P., Lowenthal, J.W., Geier, M.S., Hughes, R.H. \& Bean, A.G., 2009. Prebiotics modulate immune responses in the gut-associated lymphoid tissue of chickens. J. Nutr. 139, 14041409. 
Kim, C.H., Shin, K.S., Woo, K.C. \& Paik, I.K., 2009. Effect of dietary oligosaccharides on the performance, intestinal microflora and serum immunoglobulin contents in laying hens. Kor. J. Poult. Sci. 36, 125-131.

Lomax, A.R. \& Calder, P.C., 2009. Prebiotics, immune function, infection and inflammation: A review of the evidence. Brit. J. Nutr. 101, 633-658.

Midilli, M., Alp, M., Kocabagh, N., Muglah, O.H., Turan, N., Yilmaz, H. \& Cakir, S. 2008. Effects of dietary probiotics and prebiotics supplementation on growth performance and serum IgG concentration of broilers. S. Afr. J. Anim. Sci. 38: 21-27.

Newman, K., 1994. Mannan-oligosaccharides, natural polymers with significant impact on the gastrointestinal microflora and the immune system. In: T.P. Lyons \& K.A. Jacques (ed). Biotechnology in the feed industry. Proc. Alltech 10th Annual Symposium. Nottingham University Press, UK. pp. 167-174.

Niewold, T.A., 2007. The non-antibiotic anti-inflammatory effect of antimicrobial growth promoters, the real mode of action? A hypothesis. Poult. Sci. 86, 605-609.

NRC, 1994. Nutrient requirements of poultry. Ninth revised edition. National Academy Press, Washington D.C.

Rehman, H., Vahjen, W., Kohl-Parisini, A., ljaz, A. \& Zentek, J., 2009. Influence of fermentable carbohydrates on the intestinal bacteria and enteropathogens in broilers. World's Poult. Sci. J. 65, 75-89.

Roe, M.T., Pillai, S.D., 2003. Monitoring and identifying antibiotic resistance in bacteria. Poult. Sci. 82, 622-626.

Rosen, G.D., 2007a. Holo-analysis of the efficacy of Bio-Mos $\AA^{\circledR}$ in broiler nutrition. Brit. Poult. Sci. 48, 21-26.

Rosen, G.D., 2007b. Holo-analysis of the efficacy of Bio-Mos® in turkey nutrition. Brit. Poult. Sci., 48, $27-32$.

Sadeghi, A.A., Mohammdi, A., Shawrang, P. \& Aminafshar, M., 2013. Immune responses to dietary inclusion of prebioticbased mannan-oligosaccharide and $\beta$-glucan in broiler chicks challenged with Salmonella enteritidis. Turk. J. Vet. Anim. Sci. 37, 206-213.

Sarica, S., Corduk, M., Yarim, G.F., Yenisehirli, G. \& Karatas, U., 2009. Effects of novel feed additives in wheat based diets on performance, carcass and intestinal tract characteristics of quail. S. Afr. J. Anim. Sci. 39, 144-157.

SAS, 2003. Statistical Analysis Systems User's Guide. Version 9.1 ed. SAS Institute Inc., Raleigh, North Carolina, USA.

Steel, R.G.D., Torrie, J.H. \& Dickey, D.A., 1997. Principles and procedures of statistics - A biometric approach 3rd ed, McGraw-Hill, Toronto, Canada.

Tarasewicz, Z., Szczerbinska, D., Majewska, D., Danczak, A., Romaniszyn, K. \& Gulewicz, P., 2004. Assessment of the influence of oligosaccharides isolated from pea seeds on functional quality of quail. J. Anim. Sci., 49, $257-264$.

Vahdatpour, T., Nikpiran, H., Moshaveri, A., Ahmadzadeh, A., Riyazi, S.R. \& Vahdatpour, S., 2011. Effects of active, inactive and compounded Saccharomyces cerevisiae on growth related hormones and performance of Japanese quails (Coturnix japonica). Afr. J. Biotec., 10, 15205-15211.

Yalqnkaya, Y., Gungor, T., Basala, M. \& Erdem, E., 2008. Mannan-oligosaccharides (MOS) from Saccharomyces cerevisiae in broilers, effects on performance and blood biochemistry. Turk. J. Vet. Anim. Sci., 32, 43-48. 